\title{
The Innovation Levers to Sustainability Management: Entrepreneurship, Design and Policy
}

\author{
Lotfi Belkhir ${ }^{1}$ \\ ${ }^{1} \mathrm{~W}$ Booth School of Engineering Practice, Hamilton, Canada \\ Correspondence: Lotfi Belkhir, ETB 504, W Booth School of Engineering Practice, Hamilton ON, L8S 0A3, \\ Canada. Tel: 1-905-525-9140 ext. 26078. E-mail: Belkhir@mcmaster.ca
}

Received: November 19, 2014

Accepted: January 20, 2015 Online Published: February 20, 2015

doi:10.5539/jms.v5n1p10

URL: http://dx.doi.org/10.5539/jms.v5n1p10

\begin{abstract}
We provide an actionable framework for any organization to achieve sustainability through innovation. We propose three distinct innovation levers; namely Policy, Entrepreneurship, and Design which when judiciously activated and combined, can offer a clear path to sustainability with a strong competitive edge. We start by offering a critique of the current views on the importance of innovation to the sustainability challenge, followed by a prescriptive Enterprise Roadmap to Sustainability on how to leverage the interplay between Intra/Entrepreneurship, design, and policy, focusing on management policy, in order to create an innovation-based sustainable organization. This work is the first to identify three effective levers of innovation and provides a practical methodology on how to leverage them to achieve business sustainability that is also market competitive.
\end{abstract}

Keywords: sustainability, innovation, entrepreneurship, design, policy

\section{Introduction}

There is growing agreement among the business and academic community that sustainable enterprises that have minimal negative impact on the environment (Note 1) make long-term economic sense, and companies that approach this goal by investing in innovation can make the initiative a source of competitive advantage (Lubin \& Esty, 2010; Anderson, 2009). However, little research has been done on how to focus innovation efforts in a more systematic and prescriptive manner to achieve both sustainability and a competitive advantage together. One notable exception here is the remarkable experience and practical learning that were achieved by the company Interface Carpet Inc., under the exceptional leadership of its former CEO, the late Ray Anderson, and that was described in his book, "Confessions of a Radical Industrialist" (Anderson, 2009). In the book, Anderson describes how his company's stated vision of "Zero waste and zero carbon footprint", and its innovation-based strategy, led his company to become the dominant carpet manufacturing company in the world (Anderson, 2009).

\subsection{Is Sustainability a Mega-Goal?}

Lubin and Esty (Lubin \& Esty, 2010) have suggested that sustainability, like the Quality and IT movements, is a megatrend of our time, and the roadmap to achieve sustainability should mimic the other two megatrends. Pernick and Wilder have suggested in 2007 that we are at the onset of a revolution in green technology "that is changing the places where we live and work, the products we manufacture and purchase, and the development plans of cities, regional governments, and nations around the globe (Pernick \& Wilder, 2007)". They identify in particular six major forces they call the 6 C's - Costs, Capital, Competition, China, Consumers and Climate--that in their view are driving green technology into rapid mainstream adoption. Also, the numbers don't lie; feeding this megatrend is more than $\$ 9$ billion of annual venture invested since 2008 and growing, $\$ 200$ billion a year of private sector investment in the so-called "Cleantech" (Note 2) market, and some $\$ 400$ billion earmarked by the G20 governments in stimulus funds for green tech and sustainability programs.

Like the IT and Quality movements, Lubin and Esty argued, sustainability has to become pervasive to every function, every business line and every employee of an organization. They further argued that organizations should move through the same four stages that Quality and IT went through, namely; 1-Do old things in new ways, 2-Do new things in new ways, 3-transform the core business and finally 4-create new or highly 
differentiated business models.

Rather, a roadmap needs to be found that would provide enough actionable guidance to executives to enable them to lead their organization over time through those four or similar stages of evolution towards becoming a successful sustainable organization.

Nidumolu, Prahalad and Rangaswami prescribe a five-stage innovation process in response to sustainability legislation (Nidumolu, 2009). It starts with (1) viewing compliance as opportunity, (2) making the value chain sustainable, (3) designing sustainable products and services, (4) developing new business models and finally (5) creating next-practice platforms. The common denominator across all the five stages is increasing levels of creativity and innovation in support of projects that promote sustainability.These authors make a compelling case that sustainability through innovation can achieve the best of all worlds, namely reduce cost and improve the bottom line across the value chain, while at same time delivering more sustainable products to the market place and changing the rules of competition to push the lagging organizations into either obsolescence or deep transformation.

A key question that remains to be answered is: If innovation is indeed the key driver of sustainability, what are the innovation levers that are available to those key players?

Hence any innovation-driven sustainability process needs to identify the particular levers of innovation, where innovation encompasses the broadest sense of the word and involves all the active sectors of society. We also need to understand the interplay between these levers of innovation and how we can contribute to enabling a sustainable society (not just a sustainable corporation).

The three innovation levers, and their expanded definitions from the Business Dictionary (Business Dictionary), we have identified are:

- Entrepreneurship, defined as the capacity and willingness to develop, organize and manage a new venture along with any of its risks in order to create a net value. This definition encompasses corporate venturing, often called "intrapreneurship".

- Design, is defined as the realization of a concept or idea into a configuration, drawing, model, plan, software, process or policy and which helps achieve the designated objectives of that concept or idea.

- Policy, defined in the case of Public Policy as the declared objectives that a government or party seeks to achieve and preserve the interests of national community. In the case of Management Policy, it is the set of basic principles and associated guidelines, formulated and enforced by the governing body of an organization, to direct and limit its actions in pursuit of long-term goals.

Based on the above slightly broadened but well grounded definitions, we now proceed to elaborate on how each of these levers can be used to enable innovation-based sustainability.

\section{Innovation through Entrepreneurship}

Entrepreneurship is perhaps the most unpredictable and threatening competitive force that can challenge the status quo and change the rules of competition against the established players. Entrepreneurship is also one of the most effective manifestations of innovation in creating new wealth and accelerating the obsolescence of ineffective products and rigid business models (Christensen, 1997). Entrepreneurial new businesses will often redefine customers' expectations to steal market share away from the established players, forcing them to either adapt to the changing needs of their customer base, or drop out of the race altogether (Hamel, 1998).

Unlike established companies that start with strategy, planning and resource allocation, the entrepreneurial process starts with sensing an opportunity and exploiting it. The ability to sense an opportunity is what enables the entrepreneur to identify a gap that is ill served in the market place. The ability to exploit it comes from the management skills that the entrepreneurs learned or acquired on the job and which in turn enable them and their team to disrupt the status quo (Ibrahim \& Ellis, 2002).

Historically, entrepreneurs have led society in every megatrend, be it the computer industry, the Internet, digitization, wireless communications, or social networking. It was the Japanese entrepreneurs, exemplified by the likes of Akio Morita, co-founder of Sony, who recognized the value of Deming's Total Quality Management training earlier than their American competitors, and prodded the Quality megatrend by using it as their ultimate weapon to achieve a strong competitive advantage, by improving their products quality and reducing their cost at the same time. Deming had taught the Japanese that higher quality meant lower cost, an idea foreign to most American managers. He also foresaw what would happen. Japanese entrepreneurs, observing a successful business in America, such as textiles, steel, autos, or consumer electronics to name but a few, could study the 
products, reverse engineer them, and produce them at lower cost and higher quality. Today, the annual Deming Prize is the most coveted industrial award in Japan (Tribus, 1988).

It was also entrepreneurs, this time from Silicon Valley, California, who impelled and defined the IT age by the founding of companies like Microsoft, Apple, Oracle, Intel, Yahoo, Google and so on. There's no reason a priori why it should be any different with the sustainability mega-trend. No doubt, entrepreneurship is one of the major innovation levers that can lead us to a sustainable society and, along the way, transform every industry that does not currently meet sustainability standards. Ironically, the research literature on the role of commercial entrepreneurship in sustainability remains relatively limited and most of the literature continues to focus primarily on the role and efforts of established enterprises, or limits it to (not-for-profit) social entrepreneurship (Weiss \& Legrand, 2011).

\section{Innovation through Design}

A radical approach to design is another powerful innovation lever that can make a great impact on the sustainability of any particular product or service. Large as well as small companies have proven capable of coming up with radically designed products that won the accolades of the customer place and yielded immense economic benefits and lasting competitive edge for those innovative companies. Such is the case of Apple, Sony, BMW, Canon in the technology products sector. But innovative design extends also to every other industry, and applies not only to products and services, but also to buildings, infrastructure and process design. Walmart became the largest and most successful retailer in the world partly through the design of an extremely efficient and technologically superior supply-chain. When it comes to achieving more sustainable results, innovative design is another proven lever to achieve dramatic win-win results.

One of the emerging leaders in Innovative design for sustainability is Interface Carpets. Under the leadership of its visionary CEO, Ray Anderson, Interface led the way by profoundly redesigning not only its products, e.g. the Entropy carpet, but also by redesigning its supply chain, its internal operations, its energy production and consumption, and even its own business model, switching away from the traditional sale to a lease of its carpets, in order to control the entire lifecycle of its products and achieve a radically higher level of sustainability (Anderson, 2009).

Another enlightening example is the redesign of their distribution center around fuel-cell powered pallet trucks, instead of the traditional lead-acid batteries, by Wegmans, the innovative Rochester-based (Upstate New York) family-run grocery store. When faced with the need for an increase in product storage and distribution within a limited real estate and limited maintenance budget, Wegmans resorted to switching to fuel-cell technology, by Plug Power Inc., to power their pallet trucks. The achieved results were impressive. Maintenance costs were reduced by 42 to $48 \%$, more than 4 million kilowatt hours of energy were projected to be saved, and the carbon footprint reduction was equivalent to that of 134 cars, based on the fuel cells used in the produce facility alone (Plug Power Inc.).

\section{Innovation through Policy}

While this may be the least intuitive innovation lever, it is nonetheless an essential and powerful pillar for operationalizing a constancy of purpose towards sustainable development on a collective basis. This is true both at the macro as well as the micro-economic level.

As an example, innovative policy mechanisms such as Feed-in-Tariffs (Note 3) (FIT) have been extremely effective in accelerating investments in renewable energy technologies development and market adoption worldwide. As of 2010, more than 50 countries had enacted some version of a FIT policy and other incentives such as Renewables Portfolio Standards (Note 4) (RPS), hence creating a more global market incentive for both developers, suppliers and adopters of renewable technologies, proving one more time that financial incentives are a powerful policy leverage for strategic technology and market development (Solangi, Islam, Saidur, Rahim, \& Fayaz, 2011).

We propose in this paper that a similar approach to developing innovative sustainability policies can be taken, not only by governments but also by the enterprise itself through innovative Management Policies.

When scientifically approached, policy development is a very complex and non-linear problem. Because of the intradisciplinary nature of sustainability, and the feedback of policy consequences on other decisions and even the policy itself, as suggested by Peter Senge in the "Fifth Discipline" (Senge, 2006). It must be approached with a "system-thinking" methodology. Whether it's a government, a business enterprise, or an educational institution, the policy development has to be done in an integrated approach involving all the various stakeholders within a cross-functional team, while keeping away any ideological or pre-conceived "one-size fits all" prescriptions. 
To illustrate how management policy can constitute a radical form of innovation, it's enlightening to discuss a new form of company structure that, for the first time, embeds sustainability into the company's governance itself. The idea of the B-Corporation (Note 5), where the "B" stands for benefit, was an innovation in its own right. Independently certified by a non-profit organization called B-Lab, a B-Corp legally commits to meet strict standards of accountability, performance and transparency in its environmental and social impacts, without limitations, and here lies the innovation, to its commitment to profitability or economic growth. While the idea of a corporation serving a public good is nothing new, the governance structure of the traditional C-Corp was built to exclusively serve the financial interests of its shareholders and hence expose the management team and its board of directors to civil claims by its shareholders if it strayed from that mission.

The B-Corp, by contrast, holds the directors and officers of the corporation accountable for serving both the financial interests of the shareholders as well as the non-financial interests of the broader stakeholders. The innovative power of the B-Corp lies in its potential to disrupt the business landscape by merging the for-profit and non-profit worlds into one, and delivering the kind of public good that neither of them is capable of, in a far more efficient way than both kinds of organizations on their own. In many ways, the B-Corp could destabilize its C-Corp competitors by being much more socially and environmentally responsible, while undermining the impact of some non-profits organizations that are financially dependent on a third party and hence not inherently scalable or sustainable.

A quick analysis of the current B-Corp community is quite enlightening albeit not surprising. According to the B-Lab, there are currently more than 1,200 certified B-Corps competing in 121 different industries in 38 countries. The vast majority of them are small to mid-size companies. Indeed, the total combined revenues of the B-Corps in 2012 was estimated to about \$3.4 Billions and growing at a compound annual rate (CAGR) of over $30 \%$. Also, the annual sales of the largest certified B-Corp to date, Cascade Engineering, was about $\$ 250 \mathrm{M}$ in 2010. The B-Corp structure has existed only since 2008 and the number of certified companies grew from 125 to $1200+$ certified B-Corps in six years, with only twenty seven states passing supporting legislation.

\section{Achieving a Sustainable Organization through a Three-Pronged Approach}

Viewing innovation through its three operational levers leads us to a very different strategy for achieving sustainability, both at the macro and microcosmic level. The approach becomes not a staged approach with limited applicability and unclear causality, but rather a three-pronged approach through the three natural levers of Innovation, namely (1) intra/entrepreneurship; (2) design and (3) policy, both public and management/corporate policy.

Any and every organization that seeks to becomes sustainable, be it a business (small or big), a hospital, an educational institution, a community or a whole nation, can, within its capabilities, activate and support one or more of these three levers (the more the better) to achieve a measurably higher level of sustainability. This operational approach to innovation applies even in a nested paradigm; whereas a small entrepreneurial company can also use design and policy at their company level to further accelerate their transition to higher levels of sustainability.

While the three levers of innovation are distinct, they do of course interact strongly with each other. Design, and Design Thinking in particular, should be deeply intertwined with the other two levers and is equally important for the design of a new product or a new policy. In both cases, the design is driven by an empathy for the stakeholders and the value added that the new product or policy would produce for them. Organizations aspiring to become sustainable should consciously invest the resources in these three manifestations of innovation according to their capability level. The table below suggests a roadmap for firms that desire to apply the 3 innovation levers to achieve sustainability and economic growth concurrently.

\section{The Interface Phenomenon}

Upon the reading of Paul Hawken's book, the Ecology of Commerce (Hawken, 1993) in 1993, Ray Anderson started a deep transformation of Interface Carpet towards sustainability, the company he founded in 1973. Anderson's own book "Confessions of a Radical Industrialist" published in 2009, chronicles the new strategy of the company towards "Mount Sustainability", the specific policies the company institutionalized and the game-changing results of those policies.

In Stage One, Interface mandated ambitious reduction targets in waste, energy consumption, use of renewable power sources, and reduction in harmful emissions. They also tied managers' bonuses with those reduction goals. At the same time they encouraged an entrepreneurial culture within their company and urged their staff to design and develop creative solutions. Within 10 years of implementing these measures, Interface had saved \$262 MM 
in total waste reduction, nearly doubling their net profits.

In the Second stage, a new policy for reduction of raw materials through closed-loop production cycle was instituted. This led to the formation of an entrepreneurial $R \& D$ team dedicated to developing new processes for reclaiming used material. That team designed and built a manufacturing process for the full value recycling of the plastic from end of life carpets. In 2008, Interface's introduced the ReEntry 2.0, a process that uses recycled carpet material to create new carpet tiles. This groundbreaking method attracted a great deal of sales, decreased the use of raw materials, decreased dependency on fossil fuels and decreased costs for customers. Interface processed more than 40 Million lbs. of carpet in their first year of recycling!

In Stage Three, Interface's management policy moved into deeper transformational change by rethinking their very business model, i.e. how they design, build, sell and reclaim their products. This led them to introduce and train their engineers on sustainability design principles, such as bio-mimicry, which in turn led to the development, among other products, to the Entropy Carpet, which a team of entrepreneurial designers came up with during a company-organized trip to the woods. The Entropy carpet became the hottest-selling product in the shortest amount of time. It also reduced the waste caused by replacing a whole carpet because of a worn or bad tile, by requiring replacing the defective tile only.

\section{Enterprise roadmap to sustainability (Note 6)}

The 3 Innovation Levers approach, along with the Interface journey, suggest a clearly actionable roadmap for organizations that are committed to sustainable development as a lens for disruptive innovation and a source of competitive positioning.

Below, we propose for the first time a 3-stage roadmap of an organization towards becoming a sustainable organization. The process starts from the top, through a long-term commitment to sustainability as a business strategy and deployed through a set of actionable policies with clear and measurable targets. In order to be effective, this strategy must be supported by an organizational culture that is fully aligned with the strategic intent on the one hand, and a workforce that possesses the operational and technical capability to deliver on that strategy on the other hand.

On the operational and technical capability side, the organization must systematically train and recruit the people who will know how to operationalize the company's strategic intent in the research and development, the competitive positioning, the identification of new business and product opportunities and even in the development of new business models.

The 3-stage roadmap reflects the level of maturity of the organization as it moves towards becoming an organization where sustainability is not only a lens for innovation and a source of a competitive edge, but also deeply ingrained into the DNA of the organization through its internal policies and legal governance.

\section{Stage 1: Sustainability Strategy; Organization alignment \& Capability Building}

\begin{tabular}{|l|l|}
\hline Policy & $\begin{array}{l}\text { Company-wide sustainability training } \\
\text { Set reductions targets in GHE, energy, } \\
\text { resource consumption and emissions along } \\
\text { with supporting incentive system }\end{array}$ \\
\hline Entrepreneurship & \begin{tabular}{|l|l|} 
- Encourage and reward initiative and risk- \\
taking in development of novel solutions \\
Provide a protected risk capital proof of \\
concept and validation of those novel \\
solutions
\end{tabular} \\
\hline Design & $\begin{array}{l}\text { - Employ sustainable design principles, e.g. } \\
\text { modularity, bio-mimicry, recyclability, into the } \\
\text { product design process } \\
\text { Develop quantitative measurement models } \\
\text { for sustainability impact, e.g. GHE, toxicity, } \\
\text { energy consumption, water consumption, } \\
\text { material reusability, }\end{array}$ \\
\hline
\end{tabular}




\section{Stage 2: Goal Setting; New Products \& Services}

\begin{tabular}{|c|c|c|c|}
\hline Policy & \multicolumn{3}{|c|}{$\begin{array}{l}\text { - Set strict sustainability compliance targets for suppliers } \\
\text { - Set goals and targets for switching to renewable energy }\end{array}$} \\
\hline \multirow[t]{2}{*}{ Entr } & preneurship & - & $\begin{array}{l}\text { stitutionalize entrepreneurial culture by } \\
\text { omoting the successful ones } \\
\text { radually shift resources towards emerging } \\
\text { usinesses and scale up } \\
\text { eate new brands and/or businesses that are } \\
\text { t tainted by legacy products }\end{array}$ \\
\hline & & & $\begin{array}{l}\text { - Design new products against strict sustai } \\
\text { - Design manufacturing processes that me } \\
\text { guidelines } \\
\text { - Develop and/or acquire software tools fo } \\
\text { management of sustainability on a life cy }\end{array}$ \\
\hline
\end{tabular}

\section{Stage 3: Institutionalization; Disruptive Innovation; New Business Models}

\begin{tabular}{|c|c|c|c|c|}
\hline Policy & \multicolumn{3}{|c|}{$\begin{array}{l}\text { - Mandate } 100 \% \text { renewable energy target } \\
\text { internally and } 50 \%+\text { for suppliers } \\
\text { - Become a B-Corp } \\
\text { - Hire and fire according to sustainability criteria } \\
\text { - Lead the development of industry standards and } \\
\text { share best practice }\end{array}$} & \\
\hline \multirow[t]{2}{*}{ Entr } & reneurship & \multicolumn{3}{|c|}{$\begin{array}{l}\text { - Replicate the } 3 \text { levers at the business unit level } \\
\text { - Invest in and acquire innovative startups with } \\
\text { complementary products and a dedicated } \\
\text { sustainability strategy } \\
\text { - Leverage your entrepreneurial core competency to } \\
\text { disrupt your competitors }\end{array}$} \\
\hline & & Design & \multicolumn{2}{|c|}{$\begin{array}{l}\text { - Design products that combine form, function and } \\
\text { aesthetic, but cause zero harm in any stage of their } \\
\text { lifecycle, and are }>80 \% \text { reusable. } \\
\text { - Design a supply chain that uses } 80 \%+\text { renewable energy } \\
\text { and state of the art of water preservation } \\
\text { - Design new business models that achieve higher } \\
\text { efficiencies throughout your value chain }\end{array}$} \\
\hline
\end{tabular}

\section{Discussion: Generalization of the Roadmap to a Sustainable Society}

The astute reader will quickly realize that the above Company Roadmap, consisting mainly of the three stages outlined above, could be readily generalized and adapted to other organizations or for this matter other "thematic areas", such as (i) Education (all levels), (ii) SME's (Small and Medium Enterprises) and (iii) Energy (sources, production, transportation, consumption and management). These three thematic areas, in particular, are directly and indirectly impacting the majority of any regional population, at both national and international levels of analysis.

To start with education, sustainability education for the students, teachers and staff needs to be introduced and mandated at all levels, as a matter of policy. In addition to introducing and embedding sustainability concepts and goals into the curriculum at all levels, a dynamic roadmap on how to achieve those goals through the 3 innovation levers of policy, design and entrepreneurship will foreground all the education stakeholders, starting 
with but no limited to the students, on the means to achieve those goals. The good news is that K-12 teachers have now access to high quality and readily deployable resources such as the ones developed by "Facing the Future" (Facing the Future). This organization has developed peer-reviewed resources not by adding yet another commitment to an already overloaded curriculum, but rather by embedding sustainability into all subjects in a way that makes them more engaging, relevant, and solutions oriented. Such an approach fits perfectly within our integrated roadmap for enabling a sustainable society through innovative solutions using the combined and intertwined levers of policy, design and entrepreneurship.

Small and Medium size enterprises (SME's) constituted $99.8 \%$ of the total number of businesses within Canada in 2013, making up more than $60 \%$ of the total number of paid employees (Government of Canada). This percentage is fairly comparable to that in the US (United States Census Bureau) or other developed countries. Unfortunately, sustainable development tends to be perceived as burdensome by most SME's when in fact it can be a source of competitive advantage and improvement to the bottom line if only the leaders of those SME's were to turn to innovation to embed sustainability at the strategic level in their organization. There also, our proposed roadmap can be readily adapted to guide them through the three-tiered process of becoming a sustainable and far more competitive organization.

Finally, a sustainable society could not possibly be achieved without addressing head-on the "elephant in the room", i.e. energy. A recent study by the Australian Climate Change authority concluded that "a likely (defined as $67 \%$ probability) chance of limiting global warming to less than 2 degrees above pre-industrial levels limits equates to a global carbon budget of no more than $1700 \mathrm{Gt}$ of $\mathrm{CO}_{2}$-equivalent emissions from 2000-2050" (Australian Government - Climate Change Authority). It is now well accepted that future global warming will be driven primarily by $\mathrm{CO}_{2}$ emissions that have not yet occurred, and that will be produced from the burning of fossil fuels (Matthews, 2014). It is estimated however that the potential future emission from current known reserves of oil, natural gas and coal amount to a total of $2800 \mathrm{Gt} \mathrm{CO}_{2}$ emissions (Matthews, 2014). The current fossil fuel industry with its continuing explorations, production, transportation and management infrastructure is for all intents and purposes a growing commitment to $\mathrm{CO}_{2}$ emissions. Unless we curb the rate of burning these reserves, by developing innovative renewable and emissions-free energy substitutes to this industry, our chances of staying below the 2 degrees global warming, considered by many as an aggressive tipping point for disastrous to catastrophic planetary impacts is seriously compromised (Hansen, 2013). Here also, an adaptation of our three-pronged integrated roadmap that employs a combined and 3-staged use of policy, design and entrepreneurship innovation levers can help tackle this momentous challenge.

\section{Conclusion: Innovation Is a Social Event}

In this paper, we have taken the position that Innovation is the process of creating societal value with novel thinking and, as such, is inherently a social event. Departing from the conventional approach that focuses on economic profit alone, we propose instead that true and sustainable innovation is the one that creates net benefits for society in all of the economic, social and environmental dimensions.

We've also argued that companies can do well and do good at the same time, provided they approach sustainability as a lens for disruptive innovation and a source of competitive advantage. In that vein, we proposed that innovation in support of sustainability could be advanced using three management levers - entrepreneurship, design and policy. Starting with a business strategy that adopts sustainability as a goal for innovation and a source of competitive advantage, any organization can activate these three innovation levers, starting with (1) aligning its organization's culture and building its operational and technical capabilities in an initial stage and then (2) moving upward the sustainability curve by continuing to use internal management policy to set specific and quantifiable goals and launch new competitive products and services, to finally (3) institutionalizing sustainability through governance, and deploying disruptive products and business models through design and entrepreneurship. The impact of such organization will not only threaten its competitors and compel them to move along the same direction, in the same way as the quality movement did, but it will also inspire non-competing organizations to emulate those pioneers.

We hope that other researchers in the field will seize the opportunity to adapt and test our general framework to specific companies, as well to other thematic areas, such as the three outlined in our discussion, and offer more detailed roadmaps to those societal challenges.

\section{Acknowledgments}

I am grateful to McMaster University for the research grant No. 5-55050 without which this paper would not have been possible. 


\section{References}

Anderson, R. (2009). Confessions of a Radical Industrialist: Profits, People, Purpose. Random House.

Australian Government - Climate Change Authority. (n.d.). Retrieved from http://www.climatechangeauthority.gov.au/chapter-3-global-emissions-budget-2-degrees-or-less

Business Dictionary. (n.d.). Design. Retrieved from http://www.businessdictionary.com/definition/design.html

$\begin{array}{lllll}\text { Business } & \text { Dictionary. } & \text { (n.d.). } & \text { Entrepreneurship. }\end{array}$ http://www.businessdictionary.com/definition/entrepreneurship.html

Business Dictionary. (n.d.). Policy. Retrieved from http://www.businessdictionary.com/definition/policy.html

Christensen, C. (1997). The Innovator's Dilemma. Harvard Business Review Press.

Dale, A., Dushenko, W., \& Robinson, P. (2012). Urban Sustainability - Reconnecting Space and Place. University of Toronto Press.

Deming, E. (1986). Out of the Crisis. MIT Press.

Eesley, C. E., \& Miller, W. F. (2012). Stanford University's economic impact via innovation and entrepreneurship. California: Stanford University.

Elzen, B., Frank, G., \& Green, K. (2004). System Innovation and the Transition to Sustainability - Theory, Evidence and Policy. Edward Elgar Publishing, Inc. http://dx.doi.org/10.4337/9781845423421

Facing the Future. (n.d.). Retrieved from http://www.facingthefuture.org

Fisk, P. (2010). People, Planet, Profit - How to embrace sustainability for innovation and business growth. Kogan Page Limited.

Ginzburg, I., \& Lichtenstein, Y. (n.d.). Innovation Hype, Trends and Levers. Retrieved from Demaya Innovation Practices.

Government of Canada. (n.d.). Industry Canada. Retrieved $11 \quad 29$, 2014, from http://www.ic.gc.ca/eic/site/061.nsf/eng/Home

Grimm, R., \& Amatucci, F. M. (2011). 'Reinventing' the Business Plan Process for Sustainable Start-Ups. Journal of Strategic Innovation and Sustainability, 7(1), 154-159.

Hamel, G. (1998). The Challenge Today: Changing the Rules of the Game. Business Strategy Review, 9(2), 19-26. http://dx.doi.org/10.1111/1467-8616.00062

Hansen, J. K. P.-D. (2013). Assessing "Dangerous Climate Change": Required Reduction of Carbon Emissions to Protect Young People, Future Generations and Nature. PLoS ONE, 8(12). http://dx.doi.org/10.1371/journal.pone.0081648

Hawken, P. (1993). The Ecology of Commerce: A Declaration of Sustainability. New York: Harpen Collins Publishers.

Ibrahim, B., \& Ellis, W. (2002). Entrepreneurship \& Small Business Management. Kendall/Hun Publishing Company.

Jansen, D., Ostertag, K., \& Walz, R. (2012). Sustainability Innovations in the Electricity Sector. Springer. http://dx.doi.org/10.1007/978-3-7908-2730-9

Kralingen, B. V. (2010). IBM's Transformation - From Survival to Success. Retrieved from Forbes: http://www.forbes.com/2010/07/07/ibm-transformation-lessons-leadership-managing-change.html

Lahlou, S. (2011). System Innovation for Sustainability. Greenleaf Publishing.

Lubin, D. C., \& Esty, D. A. (2010). The Sustainability Imperative. Harvard Business Review, 42-50.

Matthews, H. D. (2014). A growing commitment to future CO2 emissions. Environmental Research Letters, 9(11), 111001. http://dx.doi.org/10.1088/1748-9326/9/11/111001

Matthews, H. D., \& Solomon, S. (2014). Irreversible does not mean unavoidable. Science, 340, 438-439. http://dx.doi.org/10.1126/science.1236372

Mente, B. D. (1987). Made in Japan: The methods, motivation, and culture of the Japanese and their influence on U.S. Businesses and all Americans. Passport Books.

Nidumolu, P. A. (2009). Why Sustainability Is Now the Key Driver of Innovation. Harvard Business Review, 
87(9), 56-64.

Pernick, R., \& Wilder, C. (2007). The Clean Tech Revolution: The Next Big Growth and Investment Opportunity. Harper Collins Publishers.

Plug Power Inc. (n.d.). Plug Power Inc. Case Study "Case Study: Wegmans Food Markets, Inc. Retrieved from $\mathrm{http}$ ://www.plugpower.com/Customers/WhosUsingGenDrive.aspx

Quinn, D. (n.d.). Stimulating Creativity: 10 Key Levers Improve Innovation. Retrieved from The TRIZ Journal: http://www.triz-journal.com/content/c090504a.asp

Riddell, R. (2004). Sustainable Urban Planning: Tippin the Balance. Blackwell Publishing, Ltd. http://dx.doi.org/10.1002/9780470773703

Rogers, E. M. (1962). Diffusion of Innovations (1st ed.). New York: Free Press.

Sarkis, J., \& Brust, D. V. (2010). Facilitating Sustainable Innovation through Collaboration - A Multi-Stakeholder Perspective. Springer. http://dx.doi.org/10.1007/978-90-481-3159-4

Senge, P. (2006). The Fifth Discipline. Crown Business.

Solangi, K., Islam, M., Saidur, R., Rahim, N., \& Fayaz, H. (2011). A review on global solar energy policy. Renewable and Sustainable Energy Reviews, 15(4), 2149-2163. http://dx.doi.org/10.1016/j.rser.2011.01.007

Stoner, J., \& Charles, W. (2010). Global Sustainability as a Business Imperative. Palgrave MacMillan. http://dx.doi.org/10.1057/9780230115439

Tata Management Training Cenre. (n.d.). The Twelve Levers of Innovation. Retrieved from $\mathrm{http}: / / \mathrm{tm} t \mathrm{tata}$.com/twelve_levers\%20_innovation.asp

The World Bank. (2010). Innovation Policy: A Guide for Developing Countries. The World Bank. Washington, DC: The World Bank. http://dx.doi.org/10.1596/978-0-8213-8269-1

Tribus, M. (1988). Deming's way. Mechanical Engineering, (7), 26-30.

Tukker, A., Charter, M., Vezzoli, C., STi, E., \& Andersen, M. (2008). System Innovation for Sustainability 1 Perspectives on Radical Changes to Sustainable Consumption and Production. Greenleaf Publishing Limited.

United States Census Bureau. (n.d.). Statistics about Business Size (including Small Business) from the U.S. Census Bureau. Retrieved from United States Census Bureau: http://www.census.gov/econ/smallbus.html

United States Patent Office. (n.d.). General Information Concerning Patents. Retrieved from http://www.uspto.gov/patents/resources/general_info_concerning_patents.jsp\#heading-4

Urabe, K., Child, J., \& Kagono, T. (n.d.). Innovation and Management: International Comparisons. De Gruyter.

Weiss, D., \& Legrand, C. (2011). Innovative Intelligence: The Art and Practice of Leading Sustainable Innovation in your Organization. John Wiley \& Sons Canada Ltd.

\section{Notes}

Note 1. A "sustainable business" or a business that achieves "sustainability" in this paper, is defined in the same sense as a "green business", which is an enterprise that has minimal, and ultimately zero, negative impact on the global or local environment, community, society or economy - an organization that strives to meet the triple bottom line. This is not to be confused with "sustainable competitive advantage" which we use extensively in this paper, and by which we mean a "durable" or "maintainable" competitive advantage.

Note 2. Cleantech usually refers to any product or services that improves operational performance, productivity, or efficiency while reducing costs, inputs, energy consumption, waste, or environmental pollution. Cleantech is often associated with venture capital funds, including NTEC, Cleantech Ventures, and Foundation Capital.

Note 3. A feed-in tariff (FIT) is a policy mechanism designed to accelerate investment in renewable energy technologies, via long-term contracts to renewable energy producers, typically based on the cost of generation of each technology.

Note 4. A Renewable Portfolio Standard (RPS) is a regulation that requires the increased production of energy from renewable energy sources, such as wind, solar, biomass, and geothermal.

Note 5. A benefit corporation or B corporation is a corporate form in the United States designed for-profit 
entities that want to consider society and the environment in addition to profit in their decision making and governance process. This structure helps ensure long-term strategic commitment to the triple-bottom line, while protecting management from potential shareholder actions for not exclusively maximizing shareholder value. See also http://en.wikipedia.org/wiki/Benefit_corporation.

Note 6. Source: Author's personal data, 2014.

\section{Copyrights}

Copyright for this article is retained by the author(s), with first publication rights granted to the journal.

This is an open-access article distributed under the terms and conditions of the Creative Commons Attribution license (http://creativecommons.org/licenses/by/3.0/). 